NASA Technical Memorandum 87059

\title{
An Evaluation of Oxygen/Hydrogen Propulsion Systems for the Space Station
}

R.W. Klemetson and P.W. Garrison

Jet Propulsion Laboratory

Pasadena, California

and

N.P. Hannum

Lewis Research Center

Cleveland, Ohio

URRARY ROPY

SEP $3 \quad 1985$

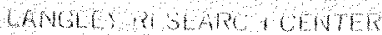

ITAABY, NASA

Hhaplon, Vholnh

Prepared for the

Twenty-first Joint Propulsion Conference cosponsored by the AIAA, SAE, ASME, and ASEE Monterey, California, July 8-10, 1985 


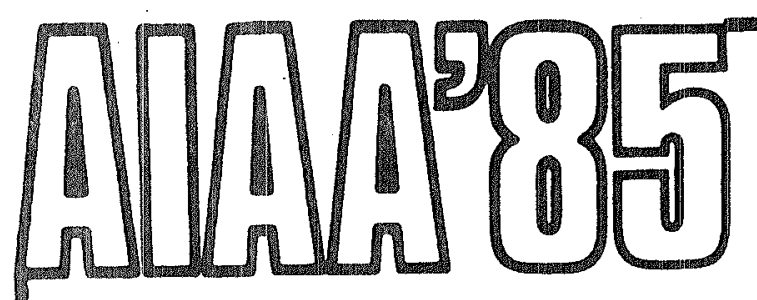

AIAA-85-1156

An Evaluation of Oxygen/Hydrogen Propulsion Systems for the Space Station

R.W. Klemetson and P.W. Garrison, Jet Propulsion Laboratory, Pasadena, California; and N.P. Hannum, NASA Lewis Research Center, Cleveland, $\mathrm{OH}$

\section{AIAA/SAE/ASME/ASEE 21st Joint Propulsion Conference July 8-10, 1985 / Monterey California}




\title{
AN EVALUATION OF OXYGEN/HYDROGEN PROPULSION SYSTEMS
}

\author{
FOR THE SPACE STATION \\ R.W. Klemetson* and P.W. Garrisont \\ Jet Propulsion Laboratory \\ California Institute of Technology \\ Pasadena, California 91109 \\ and \\ N.P. Hannum ${ }^{\dagger \dagger}$ \\ National Aeronautics and Space Administration \\ Lewis Research Center \\ Cleveland, Ohio 44135 .
}

\section{SUMMARY}

This study was conducted to develop and evaluate conceptual designs for $\mathrm{O}_{2} / \mathrm{H}_{2}$ chemical and resistojet propulsion systems for the space station.

The study considers the evolution of propulsion requirements as the space station configuration and its utilization as a space transportation node change over the first decade of operation. The characteristics of candidate $\mathrm{O}_{2} / \mathrm{H}_{2}$ auxiliary propulsion systems are determined, and opportunities for integration with the OTV tank farm and the space station life support, power and thermal control subsystems are investigated. OTV tank farm bolloff can provide a major portion of the Growth station impulse requirements and $\mathrm{CO}_{2}$ from the 1 ife support system can be a significant propellant resource, provided it is not denied by closure of that subsystem. Waste heat from the thermal control system is sufficient for many propellant conditioning requirements. This study concludes that the optimum level of subsystem integration must be based on higher level space station studies.

\section{INTRODUCTION}

This paper is an interim report on a study in progress for the NASA Lewis Research Center. Study completion and final report release is anticipated near the end of 1985. The study objective is to develop and evaluate conceptual designs for $\mathrm{O}_{2} / \mathrm{H}_{2}$ chemical and resistojet propulsion systems for application to the space station. The potential for integration of these concepts with other station subsystems is a primary interest, in addition to the goal of providing a high performance propulsion subsystem.

The propulsion system requirements used in this study are based on our interpretation of the requirements set forth in the "Space Station Reference Configuration Description." This document (ref. 1) is also the primary source for information concerning the IOC and Growth station configurations and nonpropulsion system characteristics. It was assumed that the transition from

\footnotetext{
*Member of Technical Staff; Member AIAA.

TTechnical Group Supervisor: Member AIAA.

t+Head, Primary Propulsion Research Section; Member AIAA.

This paper is declared a work of the U.S.

Government and therefore is in the public domain.
} 
the IOC to the Growth station configuration takes place during the first decade after IOC becomes operational.

The paper is organized as follows: Sections II and III provide the interpretation of the Space Station Reference Configuration propulsion requirements, and describe the influence of those requirements upon $\mathrm{O}_{2} / \mathrm{H}_{2}$ propulsion systems; Section IV considers $\mathrm{O}_{2} / \mathrm{H}_{2}$ propulsion system characteristics, e.g., thruster performance, propeliant storage and transfer and propellant resupply; Section $V$ discusses the potential for integration of candidate station subsystems, including the OTV tank farm, with propulsion; and a summary of the findings and principal conclusions for the studies conducted to date is given in Section VI.

\section{REQUIREMENTS}

Nominal and contingency requirements for both $\Delta V$ and reaction control torque functions are shown in table I. The nominal functions of drag makeup and Attitude Control System (ACS) augmentation are performed with in each resupply period. Contingency or stand-by functions of altitude transfer, backup for ACS fallure and emergency maneuvers may occur at any time, but would not be expected to repeat within each resupply period. The magnitude of the total impulse required for both nominal and contingency functions increases over the life of the station from increases in station mass and frontal area and increased transportation node activity (STS, OMV, OTV). Propellant capacity is provided on the station for all of these functions and propellant resupply is provided by the routine flights of the STS for station service every 90 days. Propellant capacity on the station for each operational phase is sized for 90 days of operations at the maximum anticipated conditions. Table II compares the estimated 90-day total impulse requirements for nominal and contingency functions for three such phases as the station evolves to the Growth configuration. The following paragraphs of this section discuss the elements and assumptions included in the total impulse requirements estimates.

\section{Drag Makeup}

The cyclic requirements for the annual total impulse to compensate for atmospheric drag are shown in figure 1. The change in requirements due to solar activity variation is shown and an evolution of space station configuration is assumed as follows:

- IOC Station FY 91 through FY 93

- Intermediate Growth station beginning FY 94

- Growth station beginning FY 99

The strong influence of atmospheric density variation upon drag makeup requirements is obvious in figure 1. For each operational phase the system is sized to accommodate the worst year, two-sigma atmosphere during the 90 days between propellant resupply visits. Long-term resupply requirements, however, are based upon the assumption of nominal atmospheric density. All drag makeup requirements assume maintenance of a constant $500 \mathrm{~km}$ altitude. 


\section{ACS Augmentation}

Operation of the space station as a transportation node requires docking, berthing, cargo transfer and departure events between the station and various space vehicles, primarily the STS, OMV, and OTV. These events are expected to exceed the torque/momentum capability of the CMG-magnetic torquer attitude control system, and augmentation by propulsive reaction control is required. A minimum thrust of $111 \mathrm{~N}(25 \mathrm{lbf})$ for thrusters acting in couples in each axis is required for these disturbances and propellant capacity is provided for 90 days of operations. Figure 2 shows the change in annual total impulse for these functions as the station evolves to the Growth configuration. The frequency of the STS, OMV and OTV operations that establish these requirements depends upon the STS traffic mode1. The STS traffic to the space station was assumed to be four flights per year for IOC operations, growing to 24 flights per year after the Growth station configuration is operational.

\section{STS/OMV/OTV Operations Model}

The model for STS, OMV and OTV operations was developed as follows:

(1) Cargo manifests for STS support of OMV and OTV operations were deve1oped as shown in table III, where the assumptions for STS cargo capability to the space station orbit, resupply model masses for OMV and OTV, and payload masses for OMV and OTV are identified.

(2) One STS flight must be dedicated to provide propellant for an OTV operation, assuming a first-generation OTV approximately the size of the Centaur $G^{\prime}$ (ref. 1).

(3) One STS flight can provide the propellant and payloads for two OMV flights, plus carry the payload for an OTV flight.

OMV/OTV operation frequency data were developed as shown by the example of table IV. This table is based on the following assumptions:

(1) One STS flight is required every 90 days for routine station support of crew, subsystems and experiments/operations. This flight has no excess capacity to support OMV/OTV operations.

(2) OMV/OTV support can be provided on additional flights according to the manifests of table III.

(3) OMV/OTV operations take place as soon as the STS schedule can provide a payload and the propellant supply for flight.

The estimated STS cargo capability is that projected by JSC for future mission studies (early 1990 s and beyond), and used in previous studies (ref. 2), except that a reduction of $24001 \mathrm{bm}$ capability has been applied because of more recent control weight increases for the filament-wound case solid rocket motor. STS flight frequency from the Eastern Test Range beyond 16 per year requires orbiter fleet and production, launch and operations facility expansion over the current STS program. 
Table $V$ shows the total impulse requirement for ACS augmentation as a function of the STS operations frequency and the associated OMV and OTV operations according to the preceding analyses. These data were used in figure 2.

\section{Contingency Functions}

Figure 3 shows the total impulse requirements for contingency, or stand-by propulsion functions as the space station configuration evolves from the IOC to the Growth configuration.

Contingency impulse for control torque is provided for 24 days of emergency $Z$ axis control in the event of entire CMG system failure. Control deadbands are opened in this situation for all but the STS Orbiter docking and berthing operations. The propellant allocation for this emergency includes CMG spin-up.

Magnetic torquer failures are not considered an emergency situation, however, the propulsion system is designed to provide for this situation if it should occur. No propellant is specifically allocated for this function, but it is assumed that propellant would be available from the contingency supply allocated for the $20 \mathrm{nmi}$ altitude transfer discussed below.

There are two contingency translation total impulse requirements. Since these functions will not be required during every 90-day period, the propellant allocation may be considered available for contingency control torque functions. The contingency transiation requirements are for space station altitude transfer and for collision avoidance.

A capability is provided to transfer the space station orbit to another circular orbit $20 \mathrm{nmi}$ above or below the initial orbit. This maneuver is assumed to be performed, if required, immediately after the STS Orbiter departs the station. The total impulse for this requirement increases directly proportional to the mass increase as the station evolves to the growth configuration.

Contingency transiation impulse is provided to avoid collision with either space debris, space station traffic or natural space objects. A propellant budget sufficient for a $5 \mathrm{ft} / \mathrm{sec}$ velocity increment is provided. Additional propellant for this function, if required, may be obtained from the allocation for the $20 \mathrm{nmi}$ orbit transfer supply, provided it has not been used. The total impulse for this requirement increases directly proportional to the mass increase as the station evolves to the growth configuration.

\section{IMPLICATIONS OF REQUIREMENTS FOR $\mathrm{O}_{2} / \mathrm{H}_{2}$ SYSTEMS}

Propellant supply systems sized to meet the requirements of table II will routinely be from 88 to 94 percent full when resupplied because of the large reserve and 2 sigma drag makeup requirements. This is shown graphically in. figure 4. For any propulsion system, the cost of providing this capability is larger, heavier tankage and the additional expense of transporting the system to orbit. There may also be some increased risk due to the increased quantity of stored propellant required to meet this requirement. Another impact of this requirement on $\mathrm{O}_{2} / \mathrm{H}_{2}$ systems is caused by the thermal control requirements of the cryogenic propellants. Based on projected cryo propellant tank thermal control technology discussed in Section IV, propellant boiloff for a dedicated 
cryogenic supply system sized to meet the reserve requirement will be up to 80 percent of the nominal usage presented in table II. If this bolloff is vented overboard, the performance of the $\mathrm{O}_{2} / \mathrm{H}_{2}$ system is significantly degraded.

utilization of bolloff for reboost and reaction control functions requires that these fluids be collected and stored in high pressure accumulators. The size and complexity of these systems can be minimized by scheduling reboost burns more frequentiy.

Boiloff penalties can be minimized by reducing the reserve requirement and by relying on noncryogenic storage for some portion of the reserve requirement. Reserve requirements imposed by system-level considerations may ultimately be reduced based on a more in-depth evaluation of the combinations of failures and worst-case atmospheric conditions that must be addressed by the on-board system. Operational solutions such as feathering the solar arrays to reduce drag, allowing the station to drop below the nominal altitude, or flying up additional propellant, may be more optimum strategies for dealing with certain low-probability events. It should be noted that in the mid-nineties, Shuttle flights to the station may occur as frequently as two per month.

Boiloff may also be reduced by storing some portion of the propellant reserve as water. A water electrolysis-based system (ref. 3 ) has the additional advantage of greatly simplified resupply. It may be possible to routinely supply water to the station, at little or no cost, on payload volume limited shuttle flights. Power requirements, discussed later in this paper, for electrolyzing water to directly feed a 25-1bf thruster are prohibitively high. Propellants for high-thrust impulse must be stored in gas accumulators. Therefore, the feasibility of this approach will depend on the distribution of the reserve requirement between the impulse that must be available on call for immediate, high-thrust response to an emergency situation, and the impuise that can be applied over longer periods of time at a rate consistent with power availability for the electrolysis system.

\section{PROPULSION SYSTEMS CHARACTERISTICS}

This section considers the application of gaseous bipropellant $\mathrm{O}_{2} / \mathrm{H}_{2}$, warm gas $\mathrm{H}_{2}, \mathrm{H}_{2}$ resistojet, and $\mathrm{CO}_{2}$ resistojet propulsion to the space station requirements. The total impulse duty cycle has a strong influence on the propulsion system concepts. Long-term storage of cryogens is detrimental to system performance because of losses to bolloff. Storage and resupply options are considered together with accumulators, heat exchangers, pumps and electrolyzers for fluid management.

\section{Thruster Performance}

Thruster specific impulse used in this study is shown in table VI. The data are for steady-state operations and are taken from reference 4 , except for the warm gas $\mathrm{H}_{2}$ thruster, which is from reference 5 . 


\section{Propulsion System Configurations}

Gaseous thruster inlet conditions are most desirable for utilization of $0_{2}, \mathrm{H}_{2}$, and $\mathrm{CO}_{2}$ propellants. The gaseous propellants can be transferred through long lines, and inputs from various supply sources can be mixed without the need for the complex thermal conditioning equipment that would be required for cryogenic liquids. Large accumulator capacity or high-rate total impulse generation capability is required, however, to provide gaseous thruster feed to meet large total impulse increment and high-thrust station requirements.

Figure 5 is a representation of the alternative resupply, storage and feed system concepts considered in this study. A propellant flow path to the thruster would most probably be along only one of the branches shown in figure 5, however, gaseous conditions at the accumulator allows the possibility of multiple path supply from various sources in an integration mode. The propellant supply may be subcritical or supercritical cryogens from a resupply module; subcritical cryogens from the OTV tank farm; water from a resupply module; or gas from OTV tank farm bolloff or ECLSS waste.

\section{Propellant Conditioning}

Various combinations of heat and work, depending upon the propulsion sys. tem configuration, are added to the propellants to convert the storage conditions to the desired thruster inlet conditions. The electrical power system is the prime energy source for propellant conditioning. Waste heat from the thermal control system is avallable at the desired temperature level $(300 \mathrm{~K})$ at approximately $50 \mathrm{~kW}$ on the IOC configuration and possibly $100 \mathrm{~kW}$ on the Growth configuration station.

Table VII shows a wide range of power requirements for providing thrust with direct conditioning of the propellant from storage conditions without intermediate gaseous storage in accumulators. High thrust is provided with the least power requirement by a system with subcritical propellant storage, pump fed through heat exchangers to the thrusters. The propellant conditioning portion of the feed process requires $23 \mathrm{~kW}$ per 50 lbf thrust and could be provided by thermal control subsystem waste heat. The IOC waste heat could support two axes control simultaneously with this concept, while the Growth configuration could support all three axes simultaneously. Electrolysis for a $\mathrm{GH}_{2}$ resistojet feed system could provide sufficient thrust for the worst case drag compensation for a $22 \mathrm{~kW}$ power requirement. Warm gas $\mathrm{GH}_{2}$ thrusters, fed from supercritical storage tanks by heat addition pressurization (the Shuttle Orbiter fuel cell subsystem concept), and bipropellant $0_{2} / \mathrm{H}_{2}$ thrusters fed by an electrolysis system require too much power for on-demand attitude control thrust levels.

Gas accumulators in the propulsion system allow for a ready source of impulse and can reduce the operational frequency and peak power demand placed on the propellant conditioning system. If a slow charging rate is acceptable, the power to charge an accumulator by electrolysis can be moderate as shown by table VIII. An accumulator that can provide $260001 \mathrm{bf}-\mathrm{sec}$ total impulse in one blow-down cycle is thought to be the minimum practical size since this represents the attitude control augmentation requirement for one Shuttie Orbiter docking event. Table VIII compares accumulator charging by electroly. sis for a warm gas $\mathrm{GH}_{2}$ system where the $\mathrm{O}_{2}$ generated is not used by the 
propulsion system, and a bipropellant $0_{2} / \mathrm{H}_{2}$ system where all the electrolyzed products are used by propulsion. The subcritical storage concept with pump feed through waste heat exchangers shows to good advantage in minimizing accumulator charge time as it did in minimizing power demand for on-demand thrust production.

\section{Cryogen Storage}

The design of the cryo propellant storage system requires consideration of a number of options and propulsion system operational requirements. Propellants may be stored at subcritical or supercritical conditions. Resupply may be accomplished by tank changeout or by the transfer of propellant from the resupply module to the station tanks. Vacuum jacket dewar or single-wall tank technology may be used. Finally, the IOC system must be capable of evolving without major retrofits to capitalize on subsystem integration opportunities, such as OTV propellant depot boiloff, as they become available.

For the IOC station, the propellants are likely to be stored in dewar tanks at supercritical conditions, and resupply is likely to be accomplished by tank changeout. This conclusion is based on the following observations. It is not likely that the cryo propellant acquisition and transfer technology under development in the Lewis Research Center CFMF Program will be available for the IOC station. The incentive for high-performance thermal control is much greater for the station propulsion system tanks than for the resupply module tanks, but without a propellant transfer capability these tanks are the same tanks. Dewar tanks provide high performance on orbit by insuring the integrity of the insulation system during the launch phase (a concern for tanks launched wet) and are not significantly heavier than the relatively highpressure, single-wall tanks required for supercritical storage.

The advent of cryo propellant acquisition and transfer technology will make possible the use of lightweight, subcritical resupply tankage in conjunction with high thermal performance, on-orbit propellant storage system. The incentive for minimizing the weight of the resupply tanks is high since these tanks must be regularly transported to the station by the Shuttle. It may be possible to use the high-pressure, supercritical tanks of the IOC station as accumulators in the Growth station propulsion system.

As shown in figure 6 (refs. 6 to 12), a wide range of performance for cryo propellant tank thermal control has been projected. Hydrogen tank capacity requirements for the $\mathrm{O}_{2} / \mathrm{H}_{2}$ and the $\mathrm{H}_{2}$ resistojet systems are shown in this figure for the range of impulse requirements shown in table II for the IOC to Growth station. Based on thermal performance demonstrated in the oxygen Thermal Test Article (OTTA) program (Curve D, fig. 6), the hydrogen tank boiloff for the IOC $0_{2} / \mathrm{H}_{2}$ system is $190 \mathrm{7bm} / \mathrm{yr}$, which is 40 to 80 percent of the nominal hydrogen usage (table II) for this system. This is an optimistic estimate of boiloff for an IOC system since the Shuttle launch loads require a stronger, higher thermal conductivity support structure than was used in the OTTA design.

The boiloff for an IOC $\mathrm{H}_{2}$ resistojet system is $520 \mathrm{1bm} / \mathrm{yr}$, which is 30 to 50 percent of the nominal hydrogen usage for this system. The oxygen boi.1off for the IOC $0_{2} / \mathrm{H}_{2}$ system is $680 \mathrm{lbm} / \mathrm{yr}$ based on the same technology. This represents 40 to 70 percent of the nominal oxygen usage. Boiloff, as a 
percent of propellant usage for dedicated propellant storage for the Growth station, is lower in each of the above cases by approximately 10 percentage points. Uniess this bolloff can be used (i.e., used directly in a continuous thrusting mode or stored in accumulators), the performance advantage of the $\mathrm{O}_{2} / \mathrm{H}_{2}$ resistojet system will be significantly reduced.

\section{Propellant Resupply}

Replenishment of propellants can be a major factor in the life cycle cost of the space station propulsion system as shown in reference 2 . The cost of propellant replenishment is primarily due to the cost to transport the fluids and the fluid resupply module by the STS to the space station. The propellant resupply quantity required depends upon the total impulse capability required, thruster performance and propellant losses due to leakage or boiloff. The boiloff losses are a major concern for cryogenic oxygen-hydrogen systems.

Figure 7 compares the resupply requirements over one nominal solar cycle for several propellant storage concepts. The station was assumed to evolve from the IOC to the Growth configuration over the solar cycle, and the propellant plus propellant resupply module mass (resupply cargo mass) required for nominal propulsion functions over that period was determined. The resistojet $\mathrm{GH}_{2}$ thruster concept is represented at the $0_{2} / \mathrm{H}_{2}$ mixture ratio of 0 . The resupply cargo mass for the electrolys is concept assumed the propulsion system was charged for the total resupply even though propulsion utilizes all of the $\mathrm{O}_{2}$ and $\mathrm{H}_{2}$ only at the 8 to 1 mixture ratio.

The propellant resupply cargo mass is minimized with bipropellant thruster operations at an 8 to 1 mixture ratio with electrolysis of water for propellant resupply, or by development of no boiloff loss $\mathrm{O}_{2} / \mathrm{H}_{2}$ storage technology. For these conditions, $\mathrm{O}_{2} / \mathrm{H}_{2}$ systems resupply cargo mass is approximately two-thirds of state-of-the-art technology $\mathrm{N}_{2} \mathrm{H}_{4}$ systems resupply cargo mass. Integration of a no boiloff loss space station propulsion system with the OTV tank farm, and resupply system, provides for the absolute minimum station $\mathrm{O}_{2} / \mathrm{H}_{2}$ resuppiy cargo mass. State-of-the-art dewar technology results in resupply cargo mass approximately three times the water electrolysis storage concept because of boiloff losses.

\section{CANDIDATE SUBSYSTEMS FOR INTEGRATION WITH PROPULSION}

\section{Electrical Power Subsystems (EPS)}

Power generation capability of $75 \mathrm{~kW}$ for the IOC space station configuration and $300 \mathrm{~kW}$ for the Growth configuration are foreseen as station requirements in reference 1. The reference configuration concepts for power generation are Si planar solar arrays for the IOC station with evolution to a solar dynamic (Brayton or Rankine cycle) system for the Growth station.

The reference configuration concepts for EPS energy storage are Regenerative Fuel Cells (RFC) for the IOC station and thermal storage, phase change material for the Growth station. 
Table IX summarizes study findings with respect to the potential integration possibilities between $\mathrm{O}_{2} / \mathrm{H}_{2}$ propulsion subsystems and the EPS on the space station. The most attractive integration opportunity appears to be that the propulsion subsystem could provide fuel cell reactants in an emergency situation. The propellant transfer could be direct from propulsion subsystem storage tankage, if high pressure supercritical storage is provided. A potentially large purge flow would be required to maintain fuel cell power output using propellant grade reactants. Purge is required to periodically remove the buildup of inert materials (He or carbonates) from the fuel cell electrodes to prevent reduction of cell output voltage. Tests (ref. 13) of the Shuttle Orbiter fuel cells with propellant grade reactants ( 99.5 percent purity) and fuel cell grade reactants ( 99.99 percent purity) required an average 35 percent higher $\mathrm{H}_{2}$ consumption and 32 percent higher $\mathrm{O}_{2}$ consumption to provide the same power with propellant grade reactants. If electrolysis units are provided for the propulsion subsystem, fuel cell grade reactants could be provided directlly to the power system.

The propulsion subsystem could provide fuel cell reactants in an emergency, but the reverse situation does not appear to be a good integration. As shown in table IX, a considerable increase in electrolysis capacity is required for the closed, regenerative IOC fuel cell system to provide the on-demand propellant requirements of even the lowest flow rate propulsion option - $\mathrm{H}_{2}$ resistojets.

\section{Thermal Control Subsystem (TCS)}

The IOC station heat rejection load will average $100 \mathrm{~kW}$. A thermal control system using the following technologies is baselined in reference 1 to remove and dissipate this heat:

(1) A two-phase pumped ammonia $\left(\mathrm{NH}_{3}\right)$ "thermal bus"

(2) Fixed and articulated, plug-in, heat pipe radiators

(3) Phase change thermal energy storage

(4) Contact heat exchangers

(5) Cold plates

Heat rejection loads on the space station will be transmitted from their heat sources to the station radiators by a two-phase thermal bus. This bus is a series of pumped ammonia loops which accept heat loads from various devices such as a heat pipe cold plate, a capillary-grooved cold plate, a fluid-to-heat pipe heat exchanger ( $H X)$ or a heat pipe-to-heat pipe $H X$. Each ammonia loop operates at a different temperature, and each can accept heat loads from several sources. A two-phase bus requires less pumping power than a single phase bus and allows isothermal operation, providing a constant temperature heat sink.

The IOC heat load will increase dramatically as the station passes from light to shadow because the fuel cell efficiency is less than the electrolyzer efficiency $\left(n_{F C}=0.6, n_{E L}=0.95\right)$. A phase-change, paraffin material, thermal capacitor may be employed to absorb some of this load fluctuation and thereby reduce the maximum TCS requirement.

The potential integration of propulsion and the TCS is to use waste heat from the TCS to condition $\mathrm{O}_{2}$ and $\mathrm{H}_{2}$ propellant temperatures for use in the. 
various warm gas, resistojet or bipropellant thrust concepts. Table $X$ summarizes the study findings. Two of the thermal bus loops remove heat from payloads and the crew, and one removes heat from the power conditioning system and the energy storage system (regenerative fuel cells). The IOC reference configuration (ref. 1) assumes loop temperatures of 40,70 , and $90{ }^{\circ} \mathrm{F}$ for crew and payloads, and $115^{\circ} \mathrm{F}$ for power. The power system waste heat is not expected to be readily avallable for propulsion because of the physical distance between the power and propulsion systems. The maximum heat rejection from the payload and crew segments at $70^{\circ} \mathrm{F}(294 \mathrm{~K})$ is approximately $50 \mathrm{~kW}$ in the IOC station. As shown in Section IV, the power required to provide the steady-state flow rates for attitude control functions exceeds $50 \mathrm{~kW}$ per axis for most thruster concepts. It may be possible to condition propellants on a continuous basis and charge accumulators to supply propellant during thruster operation.

\section{Environmental Control/Life Support Subsystem (ECLSS)}

The IOC station is defined as having a 6-person crew. The Growth station has an 18-person crew. A two-gas $\left(\mathrm{N}_{2} / \mathrm{O}_{2}\right)$ system is used in the station for respiration, and pure $\mathrm{O}_{2}$ is used for EVA respiration. The IOC station uses a partially closed ECLSS. Food regeneration technology is not considered viable for the IOC station, but the metabolic oxygen and water cycles will be closed. Water losses are made up by "wet" food (i.e., "canned peas") instead of freeze-dried foods. $\mathrm{CO}_{2}$ is removed from the cabin air and concentrated by a regenerative process. Use of the $\mathrm{CO}_{2}$ in a resistojet could provide sufficient impulse for drag makeup in nominal atmosphere. Use of the $\mathrm{H}_{2}$ from this process in a resistojet would provide adequate impulse for drag makeup in only one-half of the years in a nominal atmosphere solar cycle. $\mathrm{CO}_{2}$ is reduced by adding $\mathrm{H}_{2}$ to give $\mathrm{H}_{2} \mathrm{O}$ and carbonaceous products ( $\mathrm{C}$ or $\mathrm{CH}_{4}$ ). Overboard venting of the carbonaceous products is not permitted. The water from $\mathrm{CO}_{2}$ reduction and from humidity condensate will be used for drinking and for food preparation (potable water). A phase change (distillation) process is used to purify hygiene water, some of which is electrolyzed to give $0_{2}$ for respiration and $\mathrm{H}_{2}$ for $\mathrm{CO}_{2}$ removal/reduction. Interruption of the ECLSS cycle to provide $\mathrm{CO}_{2}$ and $\mathrm{H}_{2}$ for propulsion would require resupply of water or $\mathrm{O}_{2}$ to that subsystem. Filtration will be used to reclaim dish/clothing wash water. $\mathrm{N}_{2}$ for the IOC station will come from cryogenic $\mathrm{LN}_{2}$ or high-pressure $\mathrm{GH}_{2}$ storage. $\mathrm{N}_{2}$ generation from $\mathrm{N}_{2} \mathrm{H}_{4}$ is a consideration for the Growth station.

Table XI outlines the ECLSS/Propulsion integration possibilities. Expansion of the water electrolysis capacity of the ECLSS is a potential source of propellant for a $\mathrm{O}_{2} / \mathrm{H}_{2}$ or $\mathrm{H}_{2}$ propulsion system. Resupply water for the electrolysis process would be part of the Shuttle cargo for space station service. An increase of 30 to 40 percent of ECLSS $\mathrm{H}_{2} \mathrm{O}$ electrolysis system production capacity could provide for the nominal IOC station propulsion requirements. Approximately the same percentage of ECLSS electrolysis system oversizing would meet the nominal requirements as the station evolves toward the Growth configuration. Another potential integration possibility with respect to electrolysis is that propulsion and ECLSS could share in the development cost of the electrolyzer while each subsystem has its own dedicated flight units. 
A space-based oxygen/hydrogen Orbital Transfer Vehicle (OTV) will require the transport and on-orbit storage of large quantities of liquid oxygen and liquid hydrogen. The potential advantages of an oxygen/hydrogen propulsion system for a space station which serves as a transportation node for such an OTV include the following: (1) the efficient use of OTV depot propellant boiloff, (2) common OTV and space station propulsion resupply, and (3) access to depot propellants for space station contingency requirements. Resupply commonality can reduce costs by permitting the use of a common tanker for the two systems. The use of depot propellant for contingencies simplifies the space station propulsion system by eliminating the need for dedicated contingency tankage. OTV depot propellant bolloff can potentially supply large quantities of propellant for space station propulsion at minimum cost. The remainder of this section will focus on a preliminary evaluation of this resource.

The propellant losses in a space-based OTV system are a function of many variables including OTV and tanker size, OTV mixture ratio, thermal control systern performance, pressurization and chilldown procedures, OTV traffic and resupply frequency. A first-order analysis of such a system was performed based on a series of assumptions that were judged to be appropriate for a first-generation system.

An OTV operating at a mixture ratio of 6 to 1 with a propellant load of $450001 \mathrm{bm}(20400 \mathrm{~kg})$ was assumed. Chilldown requirements for the OTV and fill lines were estimated to be 0.5 percent for the oxygen tank and 3.3 percent for the fuel tank starting with empty tanks at $62^{\circ} \mathrm{F}(290 \mathrm{~K})$ prior to each mission.

The STS system was assumed to be capable of delivering $600001 \mathrm{bm}$ $(27200 \mathrm{~kg}$ ) to the depot orbit which was assumed to be at $500 \mathrm{~km}$ altitude. Tanker residuals were assumed to be 2.0 percent for both propellants. Tanker bolloff was assumed to be 0.2 percent for the oxygen system and 1.0 percent for the hydrogen system (ref. 14). The propellant depot was sized based on OTV traffic, resupply frequency, system losses and the requirement to accommodate one missed resupply. Depot chilldown was not required since sufficient residuals were provided to maintain the tanks at propellant temperatures. This analysis indicates that a depot sized for $1036001 \mathrm{bm}(47000 \mathrm{~kg}$ ) propellant at a mixture ratio of approximately 5.8 is required.

Based on work presented in reference 12, a depot hydrogen tank boiloff rate of 5.0 percent per year is assumed. From the same reference, an oxygen tank boiloff rate of 2.5 percent per year is assumed. This performance is representative of advanced multilayer insulation, advanced support struts and vapor-cooled shield technology. This performance is significantly better than that presented in reference 9 and the corresponding boiloff is considered to be the minimum resource available for propulsion.

Propellant losses are presented in figures 8 to 10 as a function of the number of OTV flights per year. Total propellant supply requirements are presented in figure 11. For ten 0TV flights per year, the depot hydrogen boiloff is 1.0 percent of the total fuel supplied per year, and the depot oxygen boi.1off is 0.6 percent of the total oxidizer supplied per year. Tanker residuals and OTV chilldown losses are significantly larger than depot boiloff losses 
based on the assumptions of this analysis. Vehicle chilldown requirements were computed based on the assumption that only the heat of vaporization was avail. able for removing heat from the tank structure. A more efficient chilldown procedure which also used the sensible heat of the propellant vapor could reduce the hydrogen requirement by a factor of 0.2 and the oxygen requirement by a factor of 0.6 .

The impulse available to the station propulsion system from the spacebased depot bolloff, OTV chilldown and tanker residuals is presented in table XII. Depot boiloff alone provides approximately $1.2 \times 10^{6} 1 \mathrm{bf} .5$ with an $0_{2} / \mathrm{H}_{2}$ propulsion system operating at a specific impulse of $4361 \mathrm{bf} . \mathrm{s} / 1 \mathrm{bm}$ and a mixture ratio of 4.0 or $0.40 \times 10^{6} \quad \mathrm{lb}_{\mathrm{f}} . \mathrm{s}$ with an $\mathrm{H}_{2}$ resistojet system operating at $500 \mathrm{lbf} . \mathrm{s} / 1 \mathrm{bm}$. It should be noted that propellants are avallable at a mixture ratio of approximately 2.9. The maximum impulse is provided by consuming all the oxygen in the $\mathrm{O}_{2} / \mathrm{H}_{2}$ system and the excess hydrogen in an $\mathrm{H}_{2}$ resistojet system. This provides a total impulse of $1.3 \times 10^{6}$ lbf.s per year. Based on the assumptions of this study, OTV chilldown and tanker residual losses are as large or larger than depot losses and, as shown in table XII, can potentially increase impulse availability by a factor of six. In practice, tanker residuals will be difficult to recover. Recovery of OTV chilldown fluids will require the development of reliquifaction system technology not currently being addressed by NASA technology programs. Reliquifaction technology and $\mathrm{GO}_{2}$ and $\mathrm{GH}_{2}$ compressor technology may also be required if depot bolloff is to be stored rather than used on a frequent basis. It should also be noted that remotely locating the propellant depot (tether or free-flyer) will significantly complicate the recovery of depot bolloff.

In summary, depot boiloff alone is sufficient to supply $1.3 \times 10^{6} \mathrm{lbf} . \mathrm{s}$ which is a major portion of the growth station impulse requirement. This is true even with the advances in thermal control technology that were assumed in this analysis. Boiloff generated during OTV chilldown represents a larger. alternative resource that, in combination with depot boiloff, can provide up to $3.1 \times 10^{6} 1 \mathrm{bf} . \mathrm{s}$ per year.

A significant fraction of the OTV depot boiloff could be used for propulsion by adjusting the venting duty cycle to improve the match with the propulsion duty cycle. The thermal capacity of the depot propellants is sufficientiy high that it may be possible to allow the depot to self-pressurize between frequently scheduled (e.g., weekly) propulsion events. High-pressure gas storage (requiring $\mathrm{O}_{2}$ and $\mathrm{H}_{2}$ compressor technology) can be used to accumulate propellant for RCS functions, but this option is likely to be too heavy for storing large quantities of propellant. Liquifaction of boiloff permits high-density storage, but once accomplished, the propellant can be returned to the OTV supply system and can no longer be considered free propellant. The space-based OTV and associated depot will not be a part of the initial space station, but will be introduced at a later date as an element of the Growth station. The addition of an OTV depot to the space station will significantiy increase the mass and, therefore, represent an increase in the propulsion requirements, especially for $\Delta V$ functions. But, the advent of the OTV depot also will mean the availability of additional sources of hydrogen and oxygen as well as the technology for the in-space subcritical storage, transfer and acquisition of cryogens. A hydrogen/oxygen space station propulsion system can be integrated with the OTV depot to supplement the IOC system and meet the increasing propulsion requirements of the Growth station while capitalizing on the availability of the propellants and these advanced technologies. Both 
systems could be operated independently or they could be integrated and the gaseous distribution system could be used more as a space station utility sys. tem to supply propulsion and other users or receive fluid from other sources. The OTV depot tanks could provide the propellant for the station contingency requirements. If $\mathrm{O}_{2} / \mathrm{H}_{2}$ propulsion systems are selected initially (IOC) then these integrations can be made as the Growth station systems are added and as the required technologies become available.

\section{SUMMARY AND CONCLUSIONS}

This study has investigated the space station propulsion requirements and the application of various concepts for $\mathrm{O}_{2} / \mathrm{H}_{2}$ chemical and resistojet propulsion systems to meet those requirements. Evolutionary growth of the station assumed the IOC configuration in operation in FY 91 and the Growth configura. tion operation in FY 99. The following integration possibilities between propulsion and other space station subsystems were considered:

1. Integration with the OTV tank farm offers economical propellant resupply logistics. The potential exists for utilization of oTV tank farm bolloff, storage capacity for contingency requirements and resupply modules.

2. The thermal control system can provide waste heat sufficient for propellant conditioning where fluid is pump fed from subcritical storage through heat exchangers to the thruster, or where accumulators are recharged at a slow rate.

3. $\mathrm{CO}_{2}$ from the ECLSS can provide for nominal atmosphere drag makeup unless the ECLSS is closed and the $\mathrm{CO}_{2}$ is recycled.

Gaseous storage of propellants in accumulators provides propulsion system operational and distribution advantages, and allows for design options over the evolution of the station. Propellants can be integrated into these central resupply points as they become available from different sources.

Higher level space station system trades are required to determine the optimum level of subsystem integration.

$0_{2} / \mathrm{H}_{2}$ chemical and resistojet propulsion for the space station has the potential for the economic advantage of reduced resupply cargo mass over stateof-the-art technology $\mathrm{N}_{2} \mathrm{H}_{4}$ systems. The two paths to the realization of this economy are:

1. Advanced technology to reduce cryogen storage bolloff below the current state-of-the-art so that the high thruster performance of these systems is not diluted by storage system propellant losses.

2. Adaption of an electrolysis propellant generation concept with water being the resupply fluid. On-demand thrust production by this concept requires excessive power and so an accommodation of the impulse duty cycle by accumula. tor sizing and acceptable power level recharge rate is necessary.

The continuation of this study will expand upon the work to date with. emphas is upon: 
1. Propulsion duty cycle requirements definition and accommodation.

2. Concepts to meet the contingency and high atmospheric density drag requirements with minimal on-board propellant storage capacity.

3. Evaluation of water electrolysis for propellant resupply.

4. Evaluation of gas storage and resupply to meet duty cycle requirements, particularly in the operations to build up the IOC configuration and for early IOC operations.

5. Evaluation of the applicability of environmental control and life support system fluids to the total impulse duty cycle requirements.

\section{ACKNOWLEDGEMENTS}

The authors wish to thank Brian A. Palaszewski for characterization of the power subsystem and thermal control subsystem; Robert $H$. Frisbee for characterization of the environmental control subsystem; and Joel C. Sercel and David G. Elliott for fluid storage and transfer characterization as part of this study. The management and technical direction support of Robert $E$. Jones and Richard M. Donovan at the NASA Lewis Research Center are also appreciated.

The research described in this paper was carried out in part by the Jet Propulsion Laboratory, California Institute of Technology, under a contract with the NASA Lewis Research Center.

\section{REFERENCES}

1. "Space Station Reference Configuration Description," JSC 19989, August 1984.

2. Klemetson, R.W. and Garrison, P.W., "Space Station Propulsion Technology Study, "FY 82 Final Report, Jet Propulsion Laboratory, NASA Contract NAS7-978, JPL Internal Document D-972, December 1983.

3. Rosenberg, S.D., Judd, D.C., Garrison, P.W., "Integratable Propulsion Systems for the Space Station," Journal of Propulsion and Power, Vol. 1, Number 1, January-February 1985.

4. Donovan, R.M., Sovey, J.S. and Hannum, N.P., "Space Station Propulsion Analysis Study," AIAA Paper No. 84-1327, AIAA/SAE/ASME 20th Joint Propulsion Conference, June 11-13, 1984.

5. Richmond, R., "Space Station Advanced Development Program," MSFC, March 1984 .

6. Chronic, W.L., Baese, C.L. and Conder, R.L., "oxygen Thermal Test Article (OTTA)," Final Report/Design Manual NASA-CR-140209, Beech Aircraft Co., June $15,1973$.

7. Naes, L., "SBL LH2 Tank Bołloff Rate," Lockheed Internal Report TP-6844, August 1984 . 
8. Scarlotti, R., Beech Aircraft, Personal Communication with J.C. Sercel, October 1984 .

9. Aydelott, J., Presentation to OMV/OTV/Satellite Servicing Group of the NASA Space Station Concept Development Group, Lewis Research Center, November 1983.

10. Robinson, J.W., Giellis, R.T. and Fester, D.A., "Long-Term Cryogenic Storage Study," Martin Marietta, AFRPL Report No. TR-83-082.

11. Schuster, J., General Dynamics Corporation, Personal Communication, June 13,1984 .

12. E11iott, D.G., "Advanced Thermal Control Technology for Cryogenic Prope 1lant Thermal Control," FY 85 Quarterly Report No. 1, Jet Propulsion Laboratory, January 15, 1985.

13. Martin, R., "Lightweight Fuel Cell Powerplant Components Specification Program - Final Report," United Technologies Corporation, CFR-1565, NAS8-30637, February 22, 1980.

14. Davis, E.E., "Future Orbital Transfer Vehicle Technology Study," NASA CR-3536. 
TABLE I. - PROPULSION FUNCTIONS

\begin{tabular}{|c|c|c|}
\hline Function & \multicolumn{1}{|c|}{ Nominal } & \multicolumn{1}{c|}{ Contingency } \\
\hline$\Delta V$ & $\begin{array}{c}\text { Drag } \\
\text { makeup }\end{array}$ & $\begin{array}{l}\text { Altitude transfer } \\
\text { Collision avoidance }\end{array}$ \\
$\begin{array}{r}\text { Control } \\
\text { torque }\end{array}$ & $\begin{array}{c}\text { ACS } \\
\text { augmentation }\end{array}$ & $\begin{array}{l}\text { Z axis control } \\
\text { CMG desaturization }\end{array}$ \\
\hline
\end{tabular}

TABLE II. - TOTAL IMPULSE SUMMATION SPACE STATION AUXILIARY PROPULSION SYSTEM

\begin{tabular}{|c|c|c|c|c|}
\hline \multirow[t]{3}{*}{ Operational phase } & \multicolumn{4}{|c|}{ Total impulse, $10^{6}$ lbf-sec } \\
\hline & \multicolumn{2}{|c|}{$\begin{array}{l}\text { 90-Day requirements } \\
\text { Nominal functions }\end{array}$} & \multirow{2}{*}{$\begin{array}{l}\text { Contingency } \\
\text { functions } \\
\text { Required } \\
\text { size }\end{array}$} & \multirow[t]{2}{*}{$\begin{array}{l}\text { Total } \\
\text { capacity }\end{array}$} \\
\hline & $\begin{array}{l}\text { Average } \\
\text { usage }\end{array}$ & $\begin{array}{l}\text { Required } \\
\text { size }\end{array}$ & & \\
\hline $\begin{array}{l}\text { IOC to growth configuration } \\
\text { transition } \\
\text { FY } 91 \rightarrow F Y 94 \\
\text { FY } 95 \rightarrow F Y 2001\end{array}$ & $\begin{array}{r}0.13 \rightarrow 0.24 \\
.12 \rightarrow \quad .24\end{array}$ & $\begin{array}{r}0.9 \\
.9\end{array}$ & $\begin{array}{l}1.3 \\
2.7\end{array}$ & $\begin{array}{l}2.2 \\
3.6\end{array}$ \\
\hline Growth configuration & $.24 \rightarrow .47$ & 1.3 & 2.7 & 4.0 \\
\hline
\end{tabular}

TABLE III. - CARGO MANIFESTING FOR OMV/OTV OPERATIONS

As sumptions

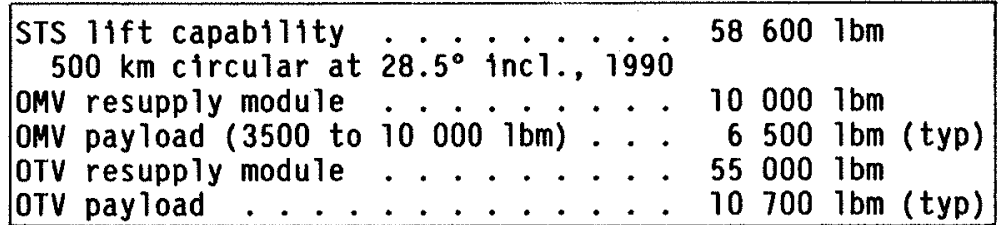

Manifest Options

\begin{tabular}{|l|c|c|c|c|}
\hline \multirow{2}{*}{ Item } & \multicolumn{2}{|c|}{ Cargo No. 1 } & \multicolumn{2}{c|}{ Cargo No. 2 } \\
\cline { 2 - 5 } & Quantity & Mass, Ibm & Quantity & Mass, Ibm \\
\hline OMV resupply module & 2 & 20000 & - & $\ldots \ldots$ \\
OMV payload & 2 & 13000 & - & $\ldots$ \\
OTV resupply module & - & -10700 & - & $\ldots . .$. \\
OTV payload & 1 & 100 \\
Total cargo requirement & - & 43700 & - & 55000 \\
Total cargo capability \\
(ref)
\end{tabular}


TABLE IV. - OTV/OMV OPERATIDNS FREQUENCY

EXAMPLE

[OTV PROP = OTV Flight propellant resupply;

OTV PL = OTV payload; OMV PL = OMV Payload;

OMV RM = OMV Flight propellant resuppiy].

\begin{tabular}{|c|c|c|c|c|c|c|c|}
\hline \multirow{2}{*}{$\begin{array}{c}\text { STS } \\
\text { Flt No. }\end{array}$} & \multicolumn{4}{|c|}{ STS OTV/OMV Cargo } & \multicolumn{2}{|c|}{ OTV/OMV FLTS } & \\
\hline & $\begin{array}{l}\text { OTV } \\
\text { PROP }\end{array}$ & $\begin{array}{l}\text { OTV } \\
\text { PL }\end{array}$ & $\begin{array}{l}\text { OMV } \\
\mathrm{PL}\end{array}$ & $\begin{array}{l}\text { OMV } \\
\text { RM }\end{array}$ & DTV & OMV & \\
\hline 1 & - & - & . & - & - & - & \\
\hline 2 & - & 1 & 2 & 2 & - & 2 & \\
\hline 3 & 1 & - & - & .. & 1 & - & \\
\hline 4 & - & 1 & 2 & 2 & - & 2 & ist quarter \\
\hline 5 & - & $\ldots$ & - & - & - & - & \\
\hline 6 & 1 & - & - & - & 1 & - & \\
\hline 7 & - & 1 & 2 & 2 & - & 2 & \\
\hline 8 & 1 & - & . & - & 1 & - & 2nd quarter \\
\hline 9 & - &.. & -. & - & -. & - & \\
\hline 10 & - & 1 & 2 & 2 & - & 2 & \\
\hline 11 & 1 & - & - & - & 1 & - & \\
\hline 12 & - & 1 & 2 & 2 & - & 2 & $3 r d$ quarter \\
\hline 13 & - & & - & $\ldots$ & $\ldots$ & - & \\
\hline 14 & 1 & - & . & . & 1 & - & \\
\hline 15 & - & 1 & 2 & 2 & - & 2 & \\
\hline 16 & 1 & - & - & . & 1 & .- & 4th quarter \\
\hline
\end{tabular}

TABLE V. - FLIGHT OPERATIONS MATRIX

\begin{tabular}{|c|c|c|c|c|c|}
\hline System & \multicolumn{5}{|c|}{ Flights per year } \\
\hline $\begin{array}{l}\text { STS } \\
\text { OMV } \\
\text { OTV }\end{array}$ & $\begin{array}{l}4 \\
0 \\
0\end{array}$ & $\begin{array}{l}6 \\
2 \\
1\end{array}$ & $\begin{array}{r}12 \\
8 \\
4\end{array}$ & $\begin{array}{r}16 \\
12 \\
6\end{array}$ & $\begin{array}{l}24 \\
20 \\
10\end{array}$ \\
\hline $\begin{array}{l}\text { Annual It } \\
\text { for ACS augmenta- } \\
\text { tion, } 10^{6} \text { lbf-sec }\end{array}$ & 0.10 & 0.16 & 0.35 & 0.47 & 0.71 \\
\hline
\end{tabular}

TABLE VI. - THRUSTER PERFORMANCE

$[N / A=$ not applicable $]$.

\begin{tabular}{|l|l|c|c|c|}
\hline Thruster & $\begin{array}{c}\text { Thrust, } \\
\mathrm{N}, \\
\mathrm{bff}\end{array}$ & $\begin{array}{c}\text { Augmentation } \\
\text { power, } \\
\mathrm{W}\end{array}$ & $\begin{array}{c}\text { Augmented gas } \\
\text { temperature, } \\
\mathrm{K}\end{array}$ & $\begin{array}{l}\mathrm{I}_{\mathrm{Sp}} \\
\text { sec }\end{array}$ \\
\hline $\mathrm{N}_{2} \mathrm{H}_{4}$ & $334(75)$ & 0 & $\mathrm{~N} / \mathrm{A}$ & 225 \\
$\mathrm{GO}_{2} / \mathrm{GH}_{2}$ at 4 to 1 & $111(25)$ & 0 & $\mathrm{~N} / \mathrm{A}$ & 436 \\
$\mathrm{GO}_{2} / \mathrm{GH}_{2}$ at 8 to 1 & $111(25)$ & 0 & $\mathrm{~N} / \mathrm{A}$ & 359 \\
$\mathrm{CO}_{2}$ resistojet & $0.45(0.1)$ & 525 & 1300 & 130 \\
$\mathrm{H}_{2}$ resistojet & $-45(0.1)$ & 1420 & 1200 & 500 \\
$\mathrm{H}_{2}$ warm gas & $111(25)$ & $(\mathrm{a})$ & 300 & 260 \\
\hline
\end{tabular}

a) $160 \mathrm{~kW}$ if $\mathrm{H}_{2}$ is stored as $22 \mathrm{~K}$ 1iquid. 
TABLE VII. - POWER FOR ON-DEMAND THRUST WITHOUT ACCUMULATORS

\begin{tabular}{|c|c|c|c|c|c|}
\hline $\begin{array}{l}\text { Propellant } \\
\text { storage } \\
\text { concept }\end{array}$ & $\begin{array}{c}\text { Fluid transfer } \\
\text { concept }\end{array}$ & $\begin{array}{c}\text { Thruster } \\
\text { type }\end{array}$ & $\begin{array}{c}\text { Total } \\
\text { thrust, } \\
\text { lbf }\end{array}$ & $\begin{array}{l}\text { Isp, } \\
\text { sec }\end{array}$ & $\begin{array}{c}\text { Power, } \\
\mathrm{kW}\end{array}$ \\
\hline $\begin{array}{l}\text { Subcritical } \\
\mathrm{O}_{2} \text { and } \mathrm{H}_{2} \\
\text { Supercritical } \\
\mathrm{H}_{2} \\
\text { Supercritical } \\
\mathrm{O}_{2} \text { and } \mathrm{H}_{2} \\
\text { Water } \\
\text { Water }\end{array}$ & $\begin{array}{l}\text { Pumps and heat } \\
\text { exchangers } \\
\text { Heat addition } \\
\text { pressurization } \\
\text { Heat addition } \\
\text { pressurization } \\
\text { Electrolysis at } \\
\text { low pressure } \\
\text { Electrolysis, } \\
\text { compressors, } \\
\text { and heat } \\
\text { exchangers }\end{array}$ & $\begin{array}{c}\mathrm{O}_{2} / \mathrm{H}_{2} \text { at } \\
8 \text { to } 1 \\
\mathrm{GH}_{2} \text { warm } \\
\text { gas } \\
\mathrm{O}_{2} / \mathrm{H}_{2} \text { at } \\
8 \text { to } 1 \\
\mathrm{GH}_{2} \\
\text { resis tojet } \\
\mathrm{O}_{2} / \mathrm{H}_{2} \text { at } \\
8 \text { to } 1\end{array}$ & $\begin{array}{l}50 \\
50 \\
50 \\
0.14 \\
50\end{array}$ & $\begin{array}{l}359 \\
260 \\
359 \\
500 \\
359\end{array}$ & $\begin{array}{r}26 \\
280 \\
40 \\
22 \\
1230\end{array}$ \\
\hline
\end{tabular}

TABLE VIII. - ACCUMULATOR CHARGING TIME FOR

26000 LBF-SEC TOTAL IMPULSE.

\begin{tabular}{|c|c|c|c|c|}
\hline $\begin{array}{c}\text { Thruster } \\
\text { system }\end{array}$ & $\begin{array}{c}\text { Propellant } \\
\text { conditioning } \\
\text { system }\end{array}$ & $\begin{array}{l}I_{\text {sp }} \\
\text { sec }\end{array}$ & $\begin{array}{c}\text { Power, } \\
\text { kw }\end{array}$ & $\begin{array}{c}\text { Charging } \\
\text { time, } \\
\text { hr }\end{array}$ \\
\hline $\begin{array}{c}\mathrm{O}_{2} / \mathrm{H}_{2} \text { at } \\
8 \text { to } 1\end{array}$ & $\begin{array}{l}\text { Pumps and } \\
\text { heat } \\
\text { exchangers }\end{array}$ & 359 & 25 & 0.74 \\
\hline $\begin{array}{c}\mathrm{O}_{2} / \mathrm{H}_{2} \text { at } \\
8 \text { to }\end{array}$ & $\begin{array}{l}\text { Electrolysis } \\
\text { and com- } \\
\text { pressors }\end{array}$ & 359 & $\begin{array}{r}25 \\
5\end{array}$ & $\begin{array}{r}7 \\
35\end{array}$ \\
\hline $\begin{array}{l}\mathrm{Gh}_{2} \text { warm } \\
\text { gas }\end{array}$ & $\begin{array}{l}\text { Electrolys is } \\
\text { and com- } \\
\text { pressor }\end{array}$ & 260 & $\begin{array}{r}25 \\
5\end{array}$ & $\begin{array}{r}87 \\
433\end{array}$ \\
\hline
\end{tabular}


TABLE IX. - EPS CHARACTERISTICS

\begin{tabular}{|c|c|}
\hline $\begin{array}{l}\text { Potential integration } \\
\text { with propulsion }\end{array}$ & Study findings \\
\hline $\begin{array}{l}\text { Fuel cell electrolysis } \\
\text { provides } 0_{2} / \mathrm{H}_{2} \\
\text { for prop. }\end{array}$ & $\begin{array}{l}\text { Large increase in electrolyzer } \\
\text { capacity required } \\
\dot{\mathrm{m}}_{\mathrm{H}_{2} \mathrm{O}}=37 \mathrm{~kg} / \mathrm{hr} \text { for IOC EPS } \\
\dot{\mathrm{m}}_{\mathrm{H}_{2} \mathrm{O}}=227 \mathrm{~kg} / \mathrm{hr} \text { required } \\
\dot{\mathrm{m}}_{\mathrm{H}_{2} \mathrm{O}}=4 \mathrm{~kg} / \mathrm{hr} \text { required for } \\
\text { resistojet }\end{array}$ \\
\hline $\begin{array}{l}\text { Propulsion provides } \\
\mathrm{O}_{2} / \mathrm{H}_{2} \text { for EPS } \\
\text { fuel cells }\end{array}$ & Appears viable (contingency) \\
\hline $\begin{array}{l}\text { EPS provides power for } \\
\text { prop. } \mathrm{O}_{2} / \mathrm{H}_{2} \\
\text { production by elec- } \\
\text { trolysis, and for } \\
\mathrm{O}_{2} / \mathrm{H}_{2} \text { fluid } \\
\text { management }\end{array}$ & $\begin{array}{l}\text { Megawatt requirement for on-demand } \\
\text { ACS flow rates } \\
\sim 20 \mathrm{~kW} \text { required for on-demand } \mathrm{H}_{2} \\
\text { resistojet flow rates } \\
\text { Low continuous power required to } \\
\text { charge accumulators over a } 90 \text { day } \\
\text { period }\end{array}$ \\
\hline
\end{tabular}

TABLE X. - TCS CHARACTERISTICS

\begin{tabular}{|c|c|}
\hline $\begin{array}{l}\text { Potential integration } \\
\text { with propulsion }\end{array}$ & Study findings \\
\hline $\begin{array}{l}\text { Heat rejection from TCS } \\
\text { applicable to } \mathrm{O}_{2} / \mathrm{H}_{2} \\
\text { fluid management } \\
\text { (temperature condi- } \\
\text { tioning) }\end{array}$ & $\begin{array}{l}\text { Three heat rejection loops proposed } \\
\text { Power segment heat reject loop } \\
\text { (319 K) too distant from prop. to } \\
\text { be practical } \\
\text { Payload and crew segment loops } \\
\text { (294 k) max } 50 \mathrm{~kW} \text { reject (IOC) } \\
\text { Reject heat possibly applicable to } \\
\text { propulsion but: } \\
\text { Rate too low for Acs without } \\
\text { augmentation } \\
\text { Heat rate approximately continuous } \\
\text { while prop. duty cycle is not, } \\
\text { therefore reject to space also } \\
\text { required }\end{array}$ \\
\hline
\end{tabular}


TABLE XI. - ECLSS CHARACTERISTICS

\begin{tabular}{|c|c|}
\hline $\begin{array}{l}\text { Potential integration } \\
\text { with propulsion }\end{array}$ & Study findings \\
\hline $\begin{array}{l}\mathrm{CO}_{2} \text { and } \mathrm{H}_{2} \text { gases aval1- } \\
\text { able for resistojet } \\
\text { propulsion }\end{array}$ & $\begin{array}{l}\mathrm{CO}_{2} \text { and } \mathrm{H}_{2} \text { may not be available } \\
\text { because of concept of system closure. } \\
\mathrm{CO}_{2} \text { potential quantity adequate for } \\
\text { nominal atmosphere drag makeup. } \mathrm{H}_{2} \\
\text { adequate only in certain years. } \\
\mathrm{CO}_{2}=1.7 \text { to } 10.4 \text { x nominal requirement } \\
\mathrm{H}_{2}=0.7 \text { to } 4.7 \times \text { nominal requirement }\end{array}$ \\
\hline $\begin{array}{l}\text { Electrolyzer capacity } \\
\text { part of ECLSS appli- } \\
\text { cable to } 0_{2} / \mathrm{H}_{2} \\
\text { production for } \\
\text { propulsion }\end{array}$ & $\begin{array}{l}\text { ECLSS electrolyzer not available for prop. } \\
\text { because of system closure } \\
\text { Electrolyzer size of } 30 \text { percent of IOC ECLSS } \\
\text { capacity provides } \mathrm{O}_{2} / \mathrm{H}_{2} \text { at } 8 \text { to } 1 \text { adequate } \\
\text { for } 90 \text { day average IOC propulsion resupply } \\
\text { requirements }\end{array}$ \\
\hline
\end{tabular}

TABLE XII. - IMPULSE AVAILABLE TO SPACE

STATION FROM SPACE-BASED OTV SYSTEM

PROPELLANT BOILOFF

[Ten OTV Flights/Year].

\begin{tabular}{|l|c|c|c|}
\hline & $\begin{array}{c}\text { Depot } \\
\text { bolloff } \\
\text { only }\end{array}$ & $\begin{array}{c}\text { Plus 0TV } \\
\text { chilldown }\end{array}$ & $\begin{array}{c}\text { Plus tanker } \\
\text { residuals }\end{array}$ \\
\hline $\begin{array}{c}\text { Total, } \\
1 \mathrm{bm} / \mathrm{yr} \\
\mathrm{H}_{2}, \mathrm{bm} / \mathrm{yr}\end{array}$ & 2970 & 6970 & 18700 \\
$\begin{array}{c}\mathrm{O}_{2}, \mathrm{bm} / \mathrm{yr} \\
\begin{array}{c}\text { Mixture } \\
\text { ratio }\end{array}\end{array}$ & 2210 & 4110 & 13690 \\
\hline
\end{tabular}

Impulse available, per year

\begin{tabular}{|c|c|c|c|c|}
\hline $\begin{array}{c}\mathrm{O}_{2} / \mathrm{H}_{2} \text { only, } \\
106^{6} 1 \mathrm{bf} . \mathrm{s}\end{array}$ & 1.2 & 2.2 & & 7.5 \\
\hline $\begin{array}{l}\text { Excess } \mathrm{H}_{2}, \\
\mathrm{lbm}\end{array}$ & 208 & 1830 & 1 & 590 \\
\hline $\begin{array}{l}\mathrm{H}_{2} \text { only, } \\
1066 \mathrm{bff} . \mathrm{s}\end{array}$ & 0.4 & 1.4 & & 2.5 \\
\hline $\begin{array}{l}\text { Excess } 0_{2}, \\
\mathrm{lbm}\end{array}$ & 2210 & 4110 & 13 & 690 \\
\hline $\begin{array}{l}\text { Both, } \\
10^{6} \text { lbf.s }\end{array}$ & 1.3 & 3.1 & & 8.3 \\
\hline
\end{tabular}




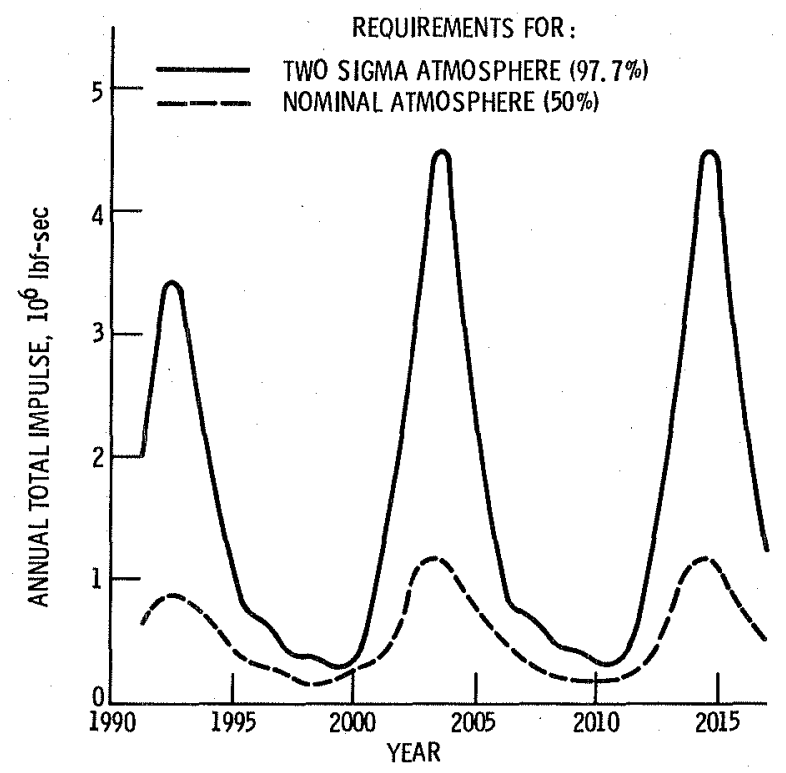

Figure 1. - Drag make-up total impulse.

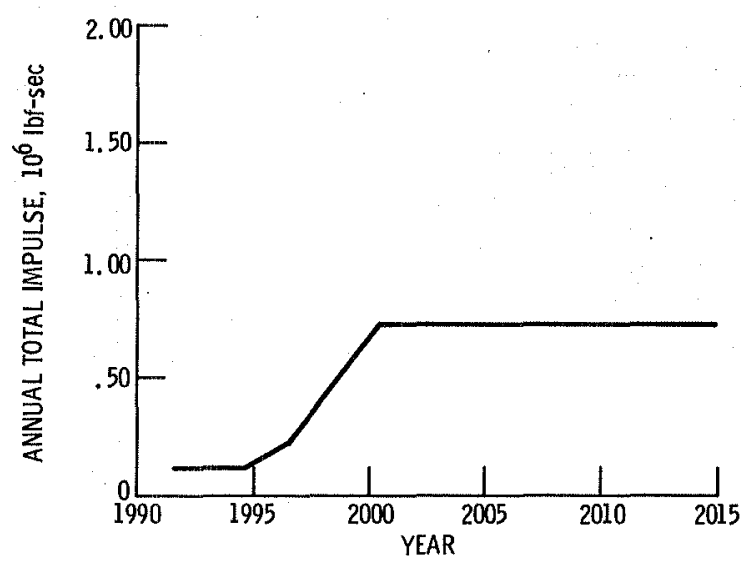

Figure 2. - Total impulse estimate for ACS augmentation. 


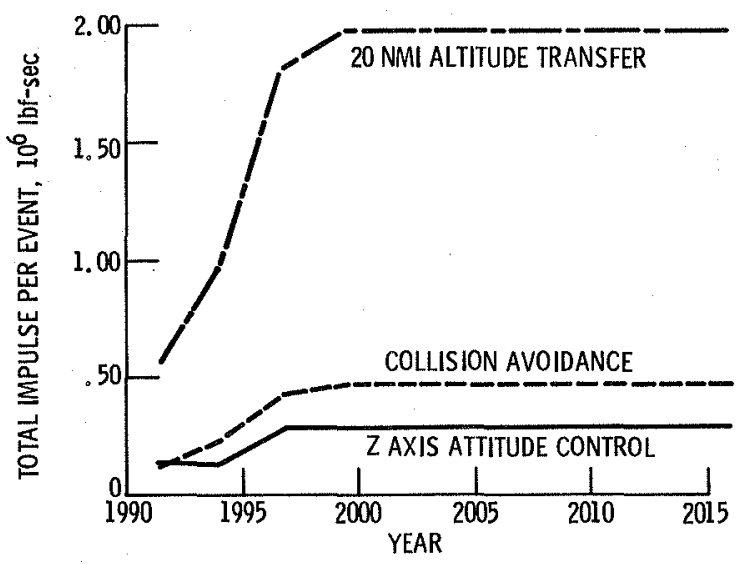

Figure 3. - Total impulse estimate for contingencies.
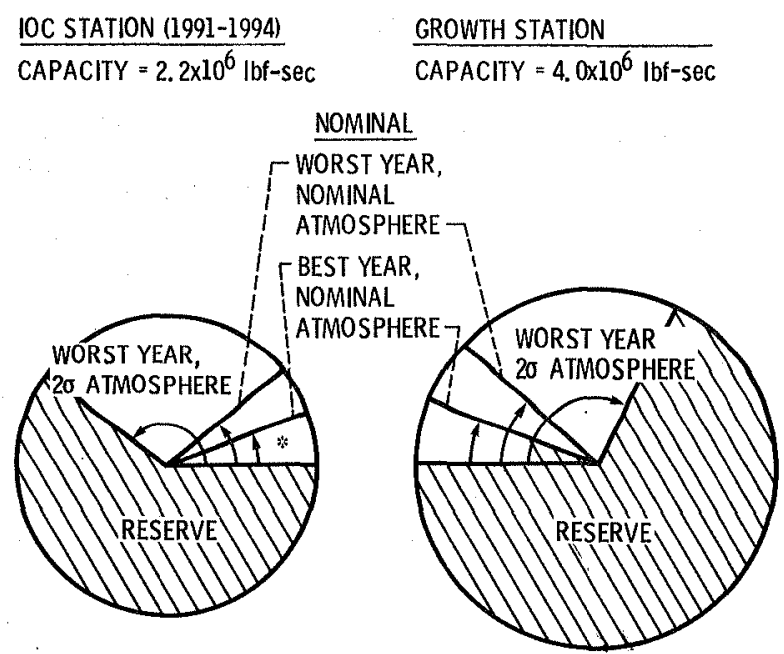

"NO PAYLOADS ASSUMED AT THIS STAGE OF DEVELOPMENT

Figure 4. - Propellant storage allocation. 


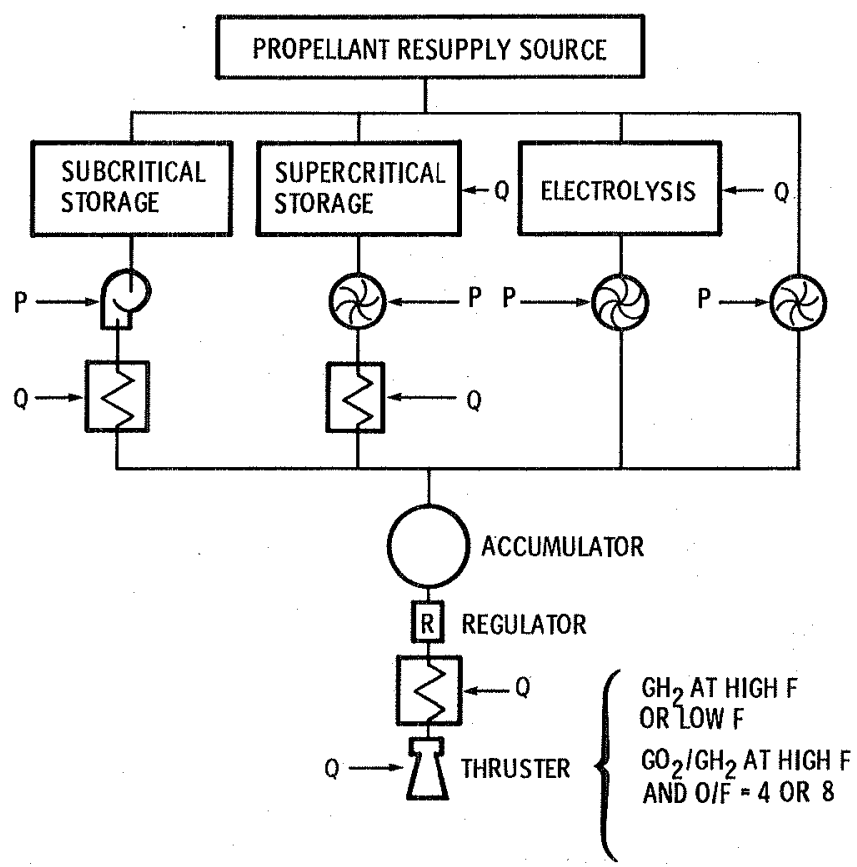

Figure 5. - Propulsion configuration concepts.

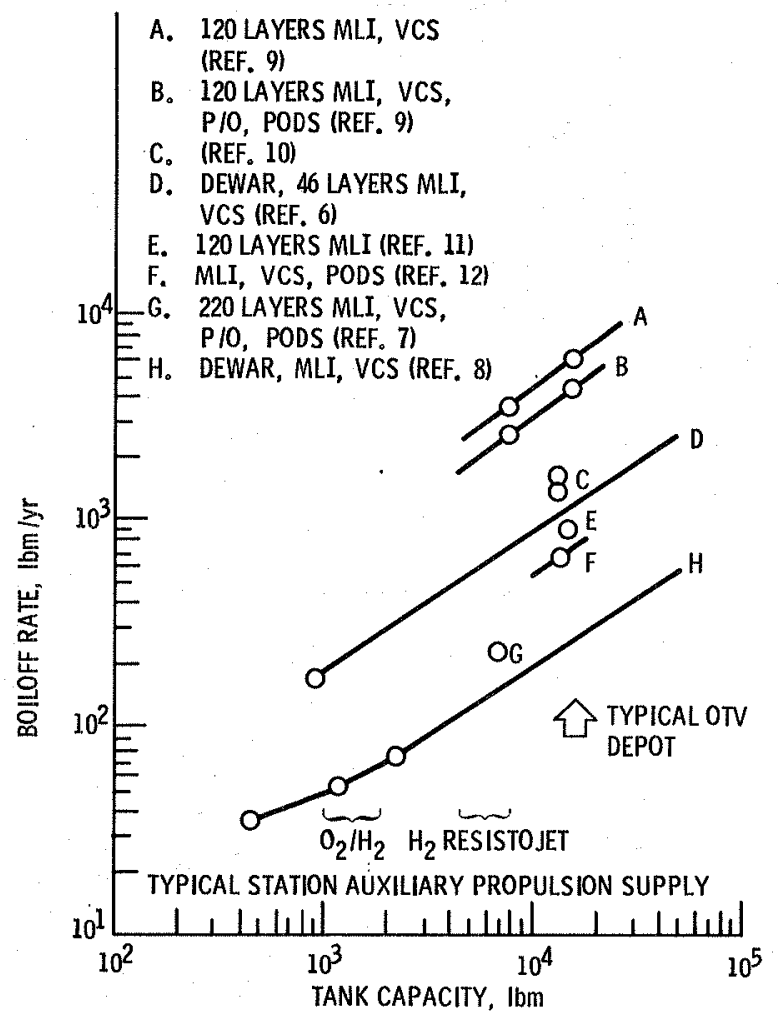

Figure 6. - Hydrogen boiloff. 


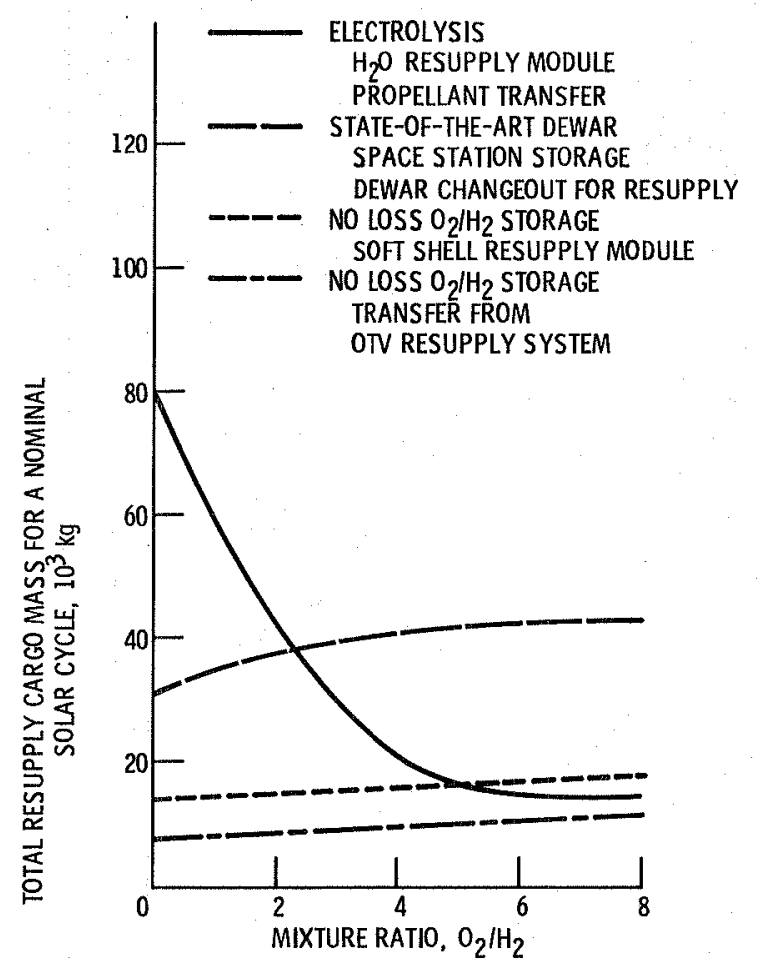

Figure 7. - Propulsion system resupply $10 \mathrm{C} \rightarrow$ growth transition space station.

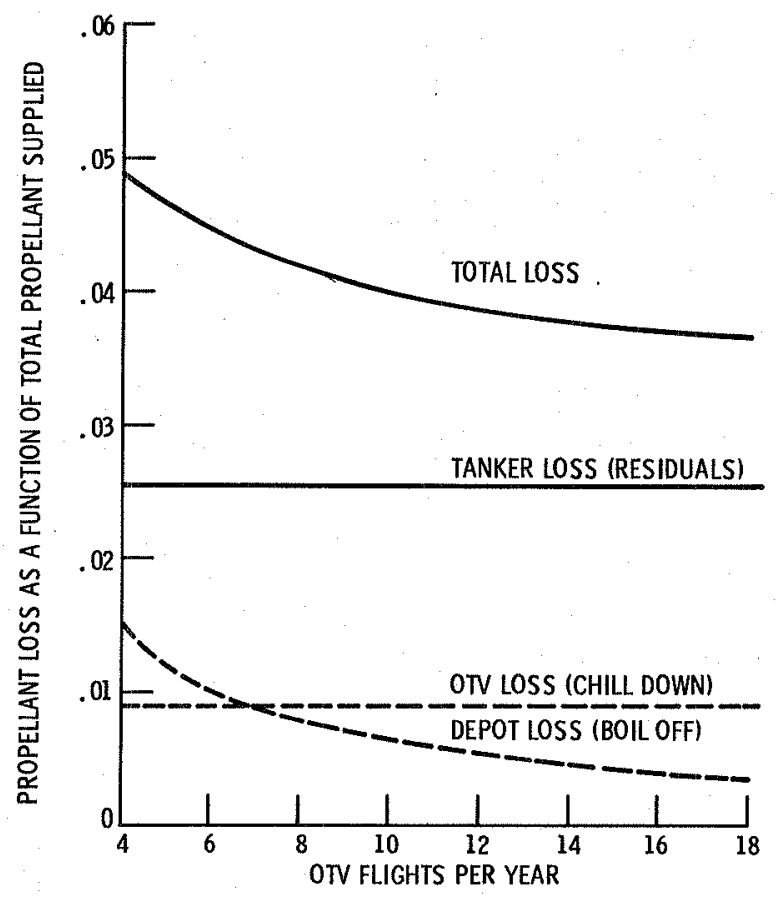

Figure 8. - OTV propellant loss. 


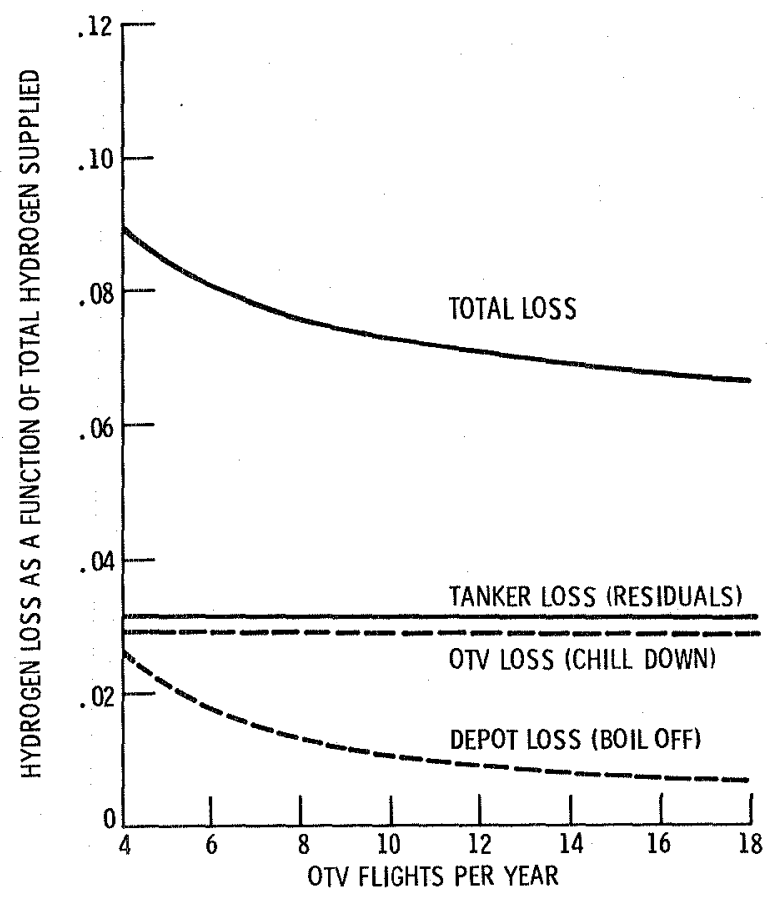

Figure 9. - OTV hydrogen loss.

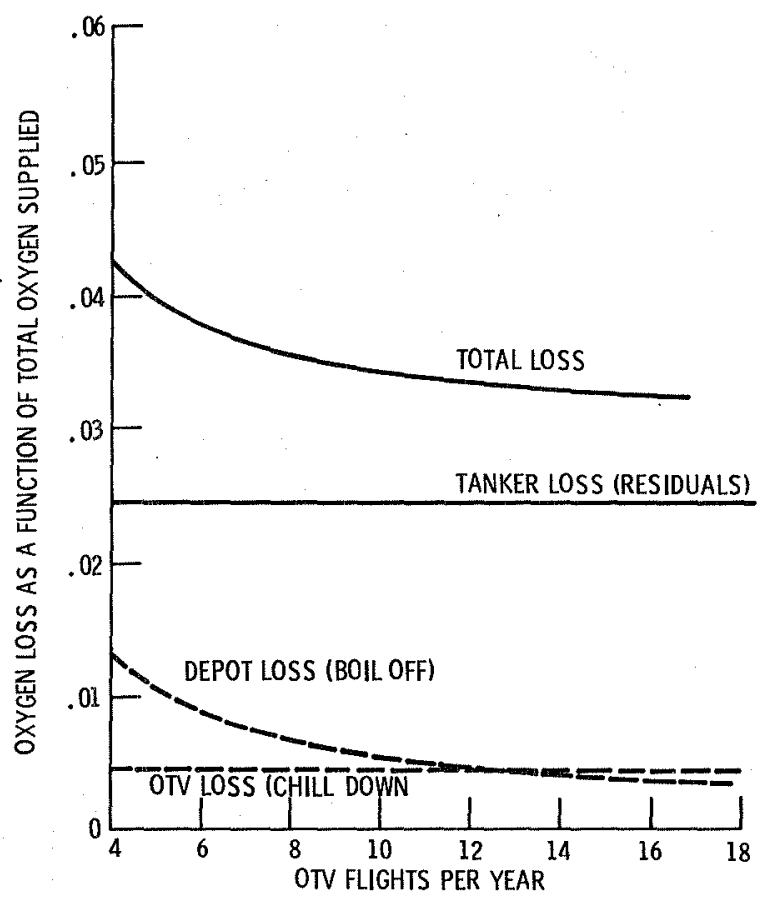

Figure 10. - OTV oxygen loss. 


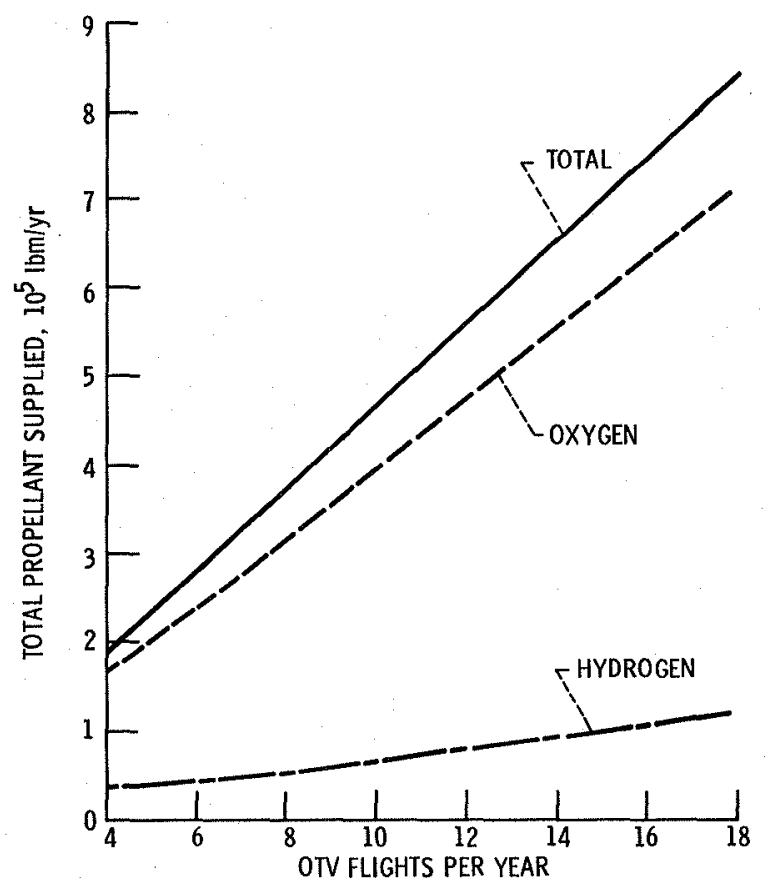

Figure 11. - Total OTV propellant requirements. 


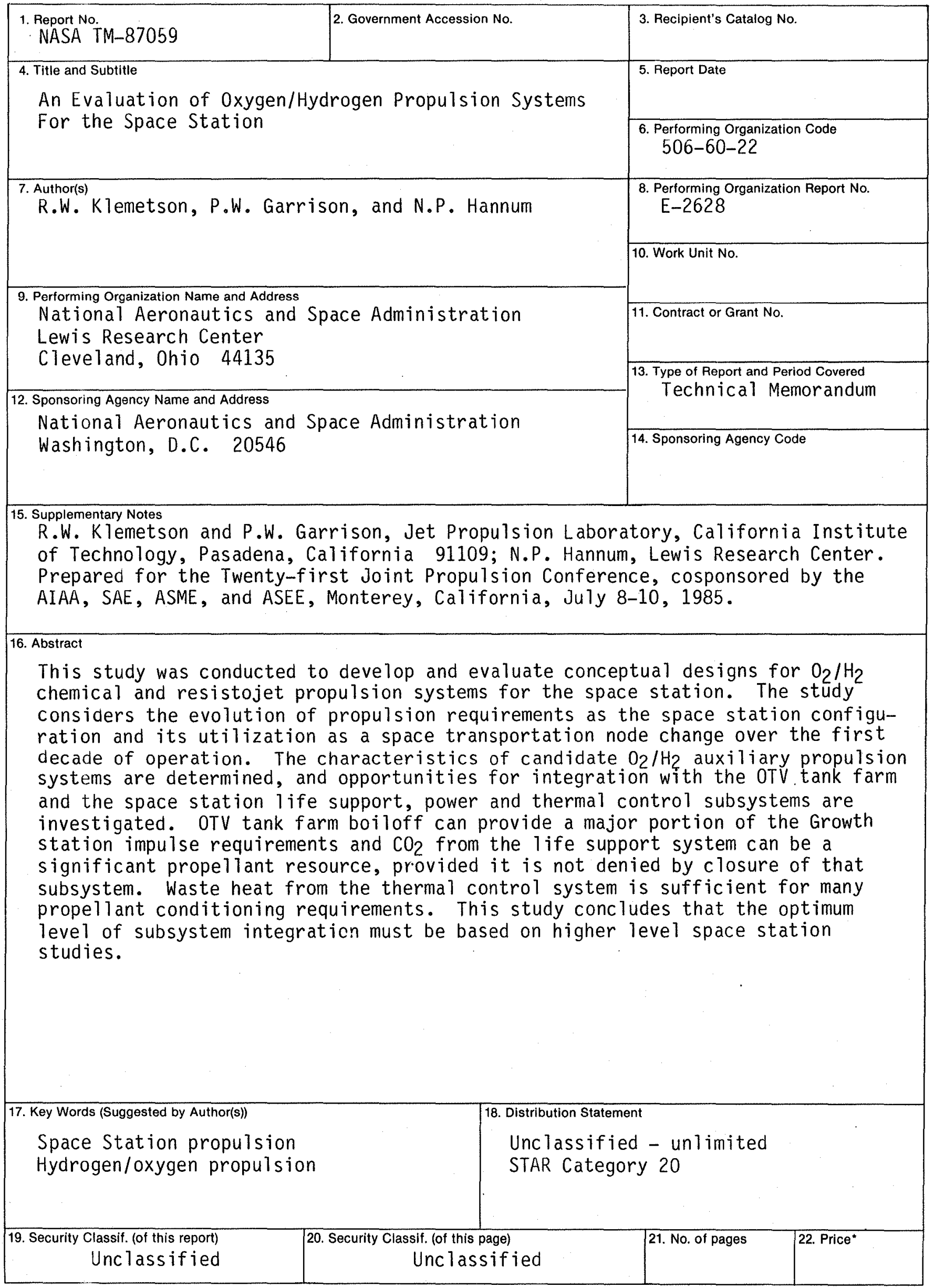

*For sale by the National Technical Information Service, Springfield, Virginia 22161 
End of Document 